\title{
Bacterial rhodopsins of newly isolated halobacteria
}

\author{
Jun Otomo, ${ }^{*}$ Hiroaki Tomioka and Hiroyuki Sasabe
}

Frontier Research Program, RIKEN Institute, Wako, Saitama 351-01, Japan

(Received 8 October 1991; revised 18 December 1991; accepted 6 January 1992)

\begin{abstract}
Several new halobacterial strains were isolated from crude solar salts commercially produced in Mexico and Australia. The presence of bacteriorhodopsin (BR)- and halorhodopsin (HR)-like pigment in their total membrane fraction was measured by flash spectroscopy and light-induced ion pumping activity. Two of these strains contained both BR- and HR-like pigments; the others contained only BR-like pigment. DNA hybridization analysis with probes from bacterioopsin and haloopsin genes revealed that the genes encoding the BR- and HR-like pigments were not homologous to those found in Halobacterium halobium R1. In addition, the presence of sensory rhodopsin (SR)- and phoborhodopsin (PR)-like pigment in these membranes was detected by flash spectroscopy. The kinetics of the cyclic photoreaction of the SR-like pigment was more than 15 times slower than that of H. halobium. A PRlike pigment existed in two strains, and the kinetics of the cyclic photoreaction of the PR-like pigment was similar to that found in $H$. halobium.
\end{abstract}

\section{Introduction}

Halobacteria, members of the domain Archaea (Woese et al., 1990), live under extremely halophilic conditions. They are found in strongly saline lakes (such as the Great Salt Lake, the Dead Sea, or the alkaline, saline lakes of East Africa) and also in the worldwide salters where salt is commercially produced from seawater by evaporation.

The first bacterial retinal-containing protein, the lightdriven proton pump bacteriorhodopsin (BR) was found in Halobacterium halobium. Since then, halorhodopsin (HR) with a light-driven chloride pump and two pigments with sensory functions, sensory rhodopsin (SR) and phoborhodopsin (PR) (or sensory rhodopsin-II) have also been found in $\boldsymbol{H}$. halobium (Oesterhelt \& Stoeckenius, 1971; Matsuno-Yagi \& Mukohata, 1977; Bogomolni \& Spudich, 1982; Tomioka et al., 1986a). Recently, these bacterial rhodopsins have been found in other halobacterial species, such as archaerhodopsin in halobacteria from Australia, and halorhodopsin- and phoborhodopsin-like pigments in the haloalkalophile Natronobacterium pharaonis (Mukohata et al., 1988; Bivin \& Stoeckenius, 1986; Duschl et al., 1990). The bacterial rhodopsin family is continuing to grow.

- Author for correspondence. Tel. (81) 484621111 ext. 6333; fax (81) 484658048 .

Abbreviations: BR, bacteriorhodopsin; HR, halorhodopsin; SR, sensory rhodopsin; PR, phoborhodopsin; bop, bacterioopsin; hop, haloopsin; sop, sensory opsin.
The amino acid sequences of bacteriorhodopsin, halorhodopsin and sensory rhodopsin in $H$. halobium are known (Dunn et al., 1981; Blanck \& Oesterhelt, 1987; Blanck et al., 1989). Because BR exists in the purple membrane as highly ordered two-dimensional crystals, its three-dimensional structure has been obtained to a resolution of about $3.5 \AA$ using electron diffraction imaging (Henderson et al., 1990). Comparison of the amino acid sequences of these three bacterial rhodopsins reveals common residues enclosing the chromophore retinal (Blanck et al., 1989).

BR has been extensively studied as a model for the elucidation of structure and function using biochemical and biophysical techniques (Stoeckenius et al., 1979). In addition, site-specific mutagenesis has identified several active-site residues for proton transport (Khorana, 1988). Three aspartic acids (positions 85, 96 and 212) appear to be essential for proton translocation to the Schiff base of the retinal (Mogi et al., 1988; Otto et al., 1990). No such experiments have been done for HR and SR yet, because of difficulties in the expression and purification of the protein, and the important residues for chloride ion transport and sensory functions are unknown. In this context, amino acid comparisons between bacterial rhodopsins isolated from other species could help to identify functionally important residues. A HR-like pigment from $N$. pharaonis has been identified, characterized and purified, and the amino acid sequence was recently determined (Bivin \& Stoeckenius, 1986; Duschl et al., 1990; Lanyi et al., 1990). On the basis of conserved 
and conservatively replaced residues between $H$. halobium $\mathrm{HR}$ and $N$. pharaonis HR, several basic residues in the helical regions have been suggested to play a role in chloride ion transport.

In search of new bacterial rhodopsins, we first isolated several new halobacterial strains from crude solar salts commercially produced in Mexico and Australia. In this report, we examine the presence of BR-, HR-, SR- and PR-like pigments in five newly isolated halobacteria using flash spectroscopic measurements and lightinduced ion transport measurements. In addition, we examine the homology of DNA from these organisms with the bacterioopsin (bop) and haloopsin (hop) genes by DNA hybridization analysis.

\section{Methods}

Collection of crude solar salts and halobacterial strains. Crude solar salts were kindly provided by Japan Tobacco Inc. These salts were sent directly from the cargo boat and their origins identified as Guerrero Negro in Mexico, and Dampier, Macleod, Port Hedland and Shark Bay in Australia. H. halobium strain Flx $3\left(\mathrm{BR}^{-}, \mathrm{HR}^{-}, \mathrm{SR}^{+}, \mathrm{PR}^{+}\right)$was a generous gift from Dr John L. Spudich. Strain ON1-bW(BR-, $\mathbf{H R}^{-}$, $\mathrm{SR}^{-}, \mathrm{PR}^{+}$carotenoid ${ }^{-}$) arose from two separate spontaneous mutations of strain Flx3.

Isolation and characterization of new halobacteria from crude solar salts. The salts $(\sim 100 \mathrm{mg})$ were first dissolved in a complex medium used for growth of $H$. halobium (Oesterhelt \& Stoeckenius, 1974). After shaking vigorously for $6-8 \mathrm{~d}$ at $40^{\circ} \mathrm{C}$, the cultures were diluted about 1000 times with the medium and the dilutions were plated on complex medium solidified with $1.5 \%$ agar (Difco). Discrete red-purple coloured colonies were picked and inoculated into the complex liquid media. After 6-8 d growth, culture solutions were diluted, plated on the agar medium and discrete colonies picked. The cells from well-isolated colonies on the third liquid-culturing and plating were observed microscopically and checked for purity. We obtained seven different isolates from the five different solar salts. The cell shape and the motility of the isolates were monitored with infrared illumination selected by an infrared transmitting filter (Hoya IR-76) from a $12 \mathrm{~V} 50 \mathrm{~W}$ tungsten-halogen lamp beam (Philips 7023) and an infrared sensitive video camera (Sony XC-37) mounted on the phase contrast microscope (Nikon Optiphot XF-Ph).

Growth of cells and preparation of cell envelope vesicles. Newly isolated strains $\boldsymbol{H}$. halobium R1 and ON1-bW were grown in the complex synthetic medium for 6-8 d. Because cells in early exponential growth phase contain larger amounts of PR than do stationary phase cells, cultures were used for the detection of PR-like pigment after $2 \mathrm{~d}$ growth. Cells were collected by centrifugation $(8000 \mathrm{~g}, 15 \mathrm{~min})$ and resuspended in $4 \mathrm{M}-\mathrm{NaCl}$ containing DNAase. Cell envelope vesicles were prepared by the freeze-thaw method. Resuspended cells were frozen at $-80^{\circ} \mathrm{C}$ overnight and thawed at room temperature. The suspension was washed with $4 \mathrm{M}-\mathrm{NaCl}$ three times by centrifugation $(20000 \mathrm{~g}, 30 \mathrm{~min})$. The envelope vesicles were further fractionated on a Ficoll density step gradient $(25,10$ and $5 \%, w / w)$ and the fraction between $10 \%$ and $5 \%$ was used for measurements of light-induced ion pump activities. In this preparation, the right-side-out envelope vesicles were mainly obtained as described ( $\mathrm{Li}$ et al., 1986). Protein concentration was determined by the Lowry method with bacteriorhodopsin as a standard.
Light-induced ion pump activities. Light-induced $\mathrm{pH}$ changes were measured with a glass pH electrode (Radiometer GK2321C) in the following apparatus. About $1.5 \mathrm{ml}$ of a sample suspension was stirred in a cylindrical glass $\mathrm{pH}$ chamber (inner diam. $15 \mathrm{~mm}$ ). A projector lamp $(300 \mathrm{~W})$ was used as a light source. The light was passed through a heatabsorbing water bath, two infrared cut filters and an orange bypass filter (>540 nm). Temperature was kept at $25^{\circ} \mathrm{C}$ using a water bath. pH measurements were performed under flowing argon.

Flash spectroscopic measurements. The monitoring beam was provided by a $12 \mathrm{~V} 100 \mathrm{~W}$ tungsten-halogen lamp (Philips 7027) passed through a monochromator (Otsuka Electronics UM-001). After passing though the sample and an additional UM-001 monochromator, the beam was focussed onto a photomultiplier (Hamamatsu Photonics R374). The photomultiplier output was fed into a current-voltage converter and then digitized with an A/D converter (Datel ADC-HZ12B, USA) and transferred to a microcomputer (Sharp MZ-2200). The actinic flash was delivered at $90^{\circ}$ to the monitoring beam with a xenon flash (Sunpak auto622) passed though a red filter (Irie R-62) for $\lambda>620 \mathrm{~nm}$ light, and a $487 \pm 6 \mathrm{~nm}$ interference filter (Irie KL-48) plus a short-cut filter (Irie Y-46) for detection of PR-like pigment. All measurements were performed at room temperature.

DNA isolation and hybridization. Genomic DNA from five new strains and $\boldsymbol{H}$. halobium $\mathrm{Rl}$ was isolated and purified according to Vogelsang et al. (1983). Chromosomal DNA was restricted with a number of endonucleases (Takara) and $\sim 1 \mu \mathrm{g}$ of each digest was fractionated on $1.0 \%(w / v)$ agarose slab gels $(6.0 \times 10.7 \mathrm{~cm})$ and blotted onto nylon membrane (Oncor) using the VacuGene Vacuum Blotting system (Pharmacia). Hybridization and detection were done using the Non-Isotopic System kit (Oncor), which uses the properties of biotin/ streptavidin interactions to visualize nucleic acid. Biotin-labelled DNA probes were prepared by incorporating biotin-modified nucleotides into DNA molecules using a standard nick-translation technique. Hybridization was done in $10 \mathrm{ml}$ Hybrisol III solution containing the denatured biotin-labelled probe (final concn. $12.5 \mathrm{ng} \mathrm{ml}^{-1}$ ) at $42{ }^{\circ} \mathrm{C}$ overnight (14-16 h). After the hybridization, the membrane was washed for $30 \mathrm{~min}$ in $0.16 \times \mathrm{SSC}$ and $0.1 \% \mathrm{SDS}$ at room temperature. Following the instructions, the blots were stained at $37^{\circ} \mathrm{C}$ in the dark for $\sim 16 \mathrm{~h}$. Biotinylated lambda DNA cut with HindIII was used as molecular mass markers (Oncor).

Partial bop (position - 36 to 839; numbering as in Dunn et al., 1981) and hop (positions 364 to 1022; numbering as in Blanck \& Oesterhelt, 1987) genes were synthesized by PCR to serve as probes. The nucleic acid sequence of probe genes was confirmed by the dideoxy method using a DNA sequencer (Applied Biosystems Model 373A).

\section{Results}

Seven well-isolated colonies were obtained from crude solar salts, and their features are summarized in Table 1. Purple membrane was isolated by washing in water from strain damp alone. From strains mac and mex, a redpurple-coloured membrane was isolated instead of purple membrane. Five strains (damp, mac, mex, port and shark) and $H$. halobium $\mathrm{R} 1$ were further investigated for the presence of retinal proteins.

Cell envelope vesicles of these five strains and $H$. halobium R1 were prepared, and flash-induced absorbance changes were measured. Fig. 1 shows the absorbance changes at $570 \mathrm{~nm}$ and $410 \mathrm{~nm}$ upon excitation with 


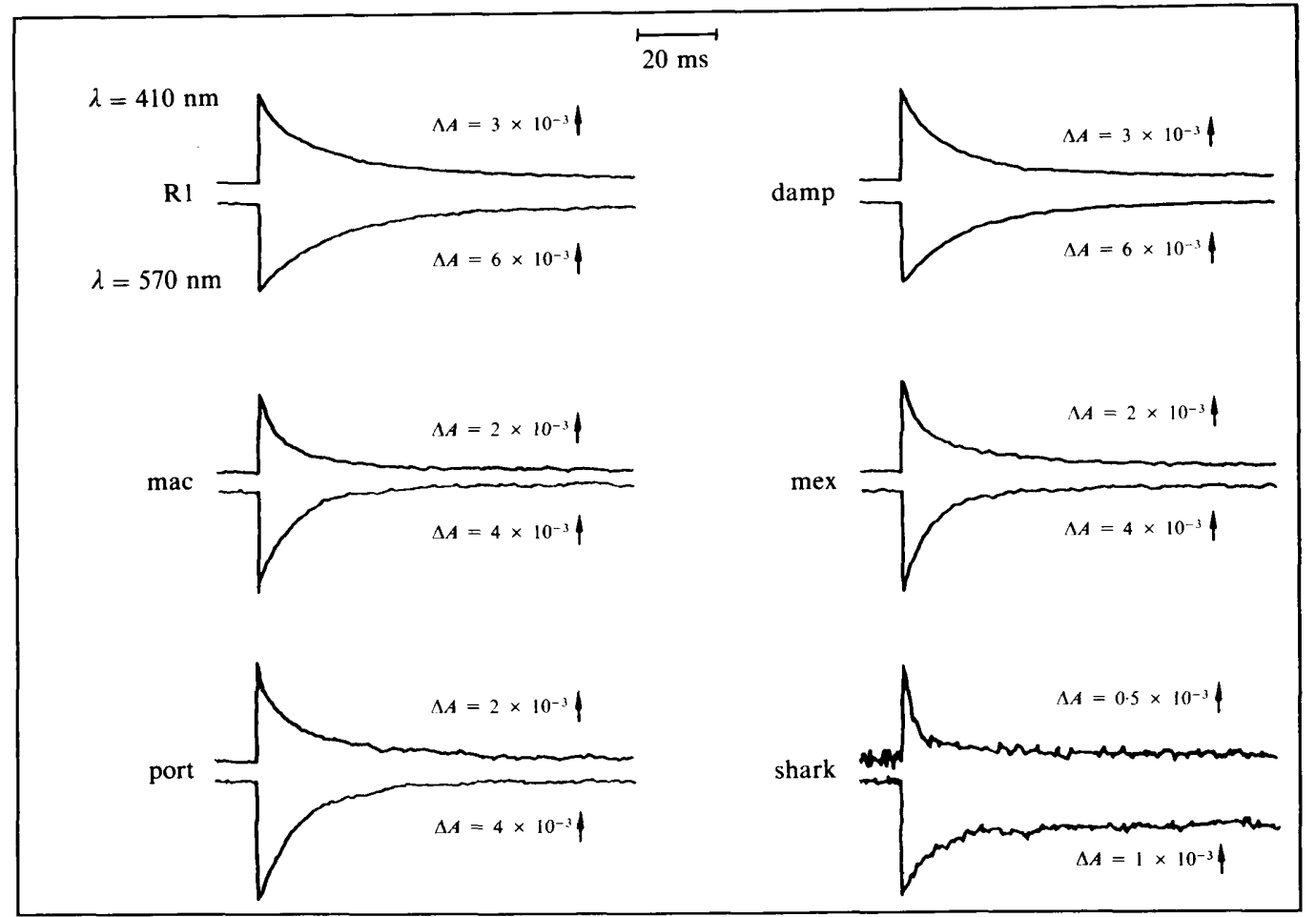

Fig. 1. Flash-induced absorbance changes in the cell envelope vesicles prepared from $H$. halobium $\mathrm{R} 1$ and five new halobacterial strains. The changes at $410 \mathrm{~nm}$ and $570 \mathrm{~nm}$ absorbances were monitored for $100 \mathrm{~ms}$ after a red actinic flash light $(>610 \mathrm{~nm})$. The samples containing $0.1 \mathrm{mg}$ protein ml-1 (strains $\mathrm{Rl}$ and damp), $0.3 \mathrm{mg}^{-1}$ protein ml-1 (strains mac, mex and port) and $2.0 \mathrm{mg} \mathrm{protein} \mathrm{ml}^{-1}$ (strain shark) total membrane protein were suspended in $4 \mathrm{M}-\mathrm{NaCl}$ and $25 \mathrm{~mm}-\mathrm{PIPES}$ at $\mathrm{pH} \mathrm{7.0.} \mathrm{The} \mathrm{traces} \mathrm{were} \mathrm{the} \mathrm{averages} \mathrm{of} 20$ (strains R1, damp, mac, mex and port) and 40 (strain shark) flashes.

Table 1. Summary of features of seven halobacterial strains newly isolated from crude solar salts

Salts from Guerrero Negro in Mexico, and Dampier, Macleod, Port Hedland and Shark Bay in Australia were collected. Strains were named after the place at which the salt was produced. The cell shape and the motility were monitored with the phase contrast microscope. The presence of purple membrane was tested by washing the total membrane fraction in water.

\begin{tabular}{|c|c|c|c|c|c|}
\hline Name & Origin & Colour & Shape & Motility & $\begin{array}{c}\text { Purple } \\
\text { membrane }\end{array}$ \\
\hline damp & Australia & Purple & $\begin{array}{c}\text { Rods } \\
1.0 \sim 6.0 \mu \mathrm{m}\end{array}$ & + & + \\
\hline mac & Australia & Red & $\begin{array}{c}\text { Rods } \\
1.0 \sim 4.0 \mu \mathrm{m}\end{array}$ & + & - \\
\hline $\operatorname{mex}$ & Mexico & Red & $\begin{array}{l}\text { Rods } \\
1.0 \sim 6.0 \mu \mathrm{m}\end{array}$ & + & - \\
\hline port & Australia & Red & $\begin{array}{c}\text { Rods } \\
1.0 \sim 3.0 \mu \mathrm{m}\end{array}$ & + & - \\
\hline shark & Australia & Orange & $\begin{array}{l}\text { Rods } \\
1.0 \sim 6.0 \mu \mathrm{m}\end{array}$ & \pm & - \\
\hline $\operatorname{mex} 2$ & Mexico & Orange & $\begin{array}{c}\text { Spheres } \\
0.8 \sim 1.5 \mu \mathrm{m}\end{array}$ & + & - \\
\hline shark 2 & Australia & Orange & $\begin{array}{l}\text { Rods } \\
1.0 \sim 6.0 \mu \mathrm{m}\end{array}$ & + & - \\
\hline
\end{tabular}

a red flash light in the $100 \mathrm{~ms}$ time range. It is known that BR (absorption maximum $\sim 570 \mathrm{~nm}$ ) undergoes a photoreaction by light excitation, and then generates the long-lived $M$-intermediate (maximum at $\sim 410 \mathrm{~nm}$ ), whose recovery half-time is $\sim 10 \mathrm{~ms}$ (Stoeckenius et al., 1979). In all five strains, absorbance decreased at $570 \mathrm{~nm}$ and increased at $410 \mathrm{~nm}$ with a recovery half-time of 5-10 ms, indicating the presence of BR-like pigment in the cell envelope vesicles. This is further confirmed by transient absorbance changes at other wavelengths between 350 and $650 \mathrm{~nm}$ (Fig. 2). The flash-induced difference spectrum of all species shows the depletion maximum at $\sim 580 \mathrm{~nm}$ and an absorbance increase at $\sim 410 \mathrm{~nm}$ with the crossover point at $\sim 460 \mathrm{~nm}$. Therefore the absorbance changes, and the difference spectrum strongly indicates the presence of BR-like pigments. The recovery half-times at $410 \mathrm{~nm}$ in strains mac, mex, port and shark were faster than that found in $H$. halobium R1. Therefore the photocycle of the BRlike pigment in these strains is not identical to that in $H$. halobium R1. Assuming molar absorption coefficients similar to BR of $\boldsymbol{H}$. halobium, we estimated that the 

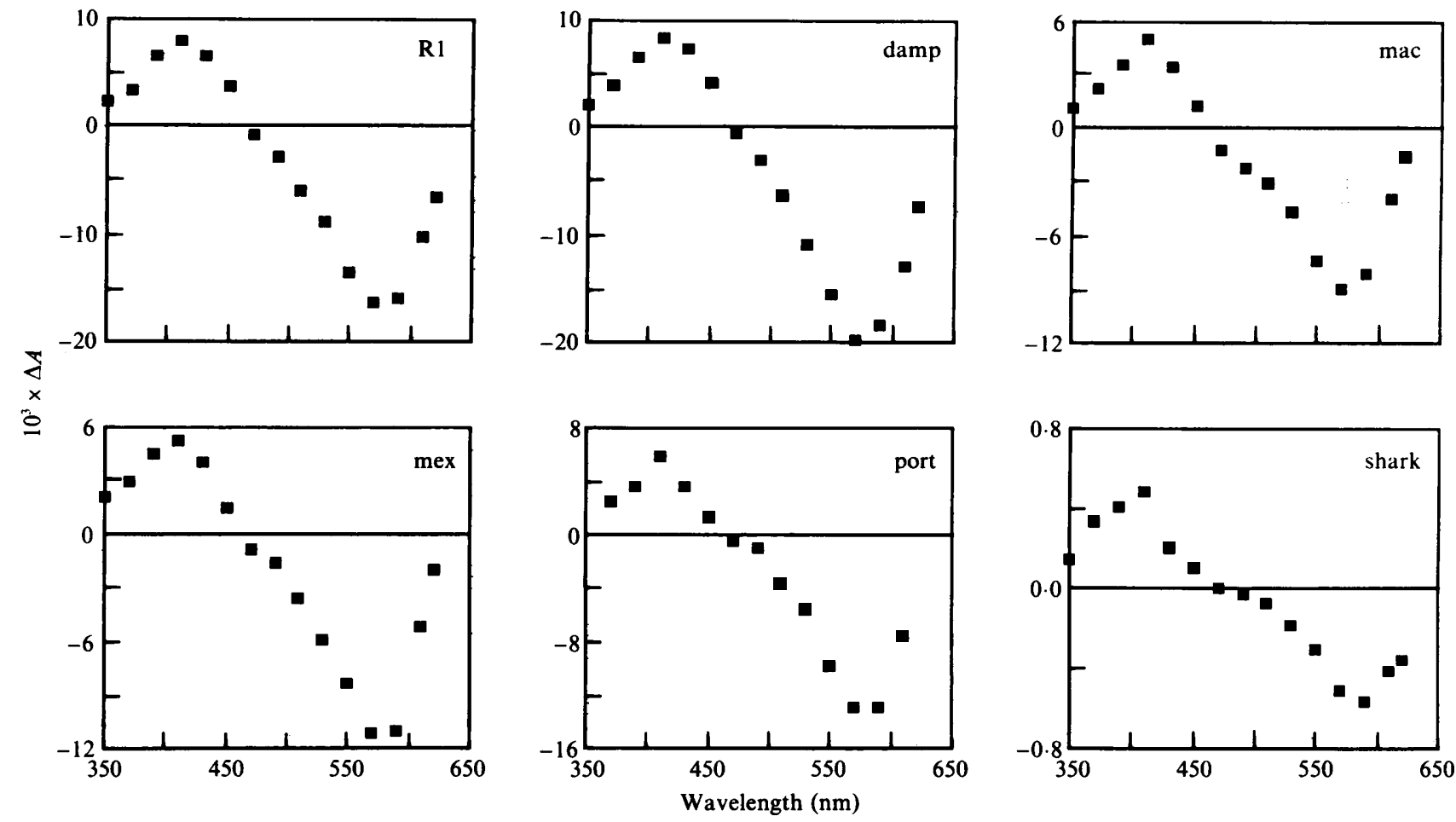

Fig. 2. Flash-induced absorbance difference spectra of $H$. halobium $R 1$ and five new halobacterial strains. Each spectrum was obtained from an absorbance change $1 \mathrm{~ms}$ after the flash at various wavelengths ( 350 to $650 \mathrm{~nm}$ ). The sample concentration is the same as described in Fig. 1.

BR-like pigments in the strains ranged from 0.3 to $104 \%$ of that in $H$. halobium R1 (Table 2).

Light-induced $\mathrm{pH}$ changes of the cell envelope vesicles were used to investigate light-induced ion pump activity (Fig. 3). In $H$. halobium $\mathrm{R} 1$, there was a rapid acidification of the external medium, followed by a slow alkalization. The fast acidification indicates the presence of BR molecules, which function as light-driven proton pumps from the inside to the outside of the vesicle. After denaturation of the other membrane proteins by the treatment with a weak acid at $40{ }^{\circ} \mathrm{C}$ (Kouyama et al., 1987), the slow alkalization disappeared (data not shown). This slow alkalization is probably caused by the counterflux of proton due to the secondary ion transport system, such as a postulated $\mathrm{Na}^{+} / \mathrm{H}^{+}$ antiporter in $\boldsymbol{H}$. halobium (Schobert \& Lanyi, 1982). In the presence of the proton ionophore CCCP, which attenuates $\mathrm{pH}$ gradients, the $\mathrm{pH}$ change was smaller. An analogous light-induced $\mathrm{pH}$ change was found in the envelope vesicle from strain damp, implying similarities between it and $H$. halobium R1. In strains mac, mex and port, a rapid and extensive acidification in the external medium was observed without acid treatment of these vesicles, indicating that these strains contain BR-like pigment. In the presence of $\mathrm{CCCP}$, a relatively large
Table 2. Relative amount of BR-like pigments in five halobacterial strains

The amount of the pigment was estimated from the light-induced absorbance changes at $410 \mathrm{~nm}$ and was expressed as percentage of the BR value for $\boldsymbol{H}$. halobium R1.

\begin{tabular}{lc}
\hline \hline Name & $\begin{array}{c}\text { BR-like } \\
(\%)\end{array}$ \\
\hline R1 & 100 \\
damp & 104 \\
mac & 19 \\
mex & 20 \\
port & 22 \\
shark & $0 \cdot 3$ \\
\hline \hline
\end{tabular}

alkalization of the external medium was observed in strains mac and mex but not port, suggesting the presence of a light-induced proton uptake. In strains mac and mex, therefore, there is a pigment functioning as an electrogenic light-induced ion pump which generates inside-negative membrane potential. In addition, this alkalization depended on chloride concentration of the medium (data not shown). These data strongly suggest the presence of a HR-like pigment which is known to function as a light-driven chloride pump from outside to 

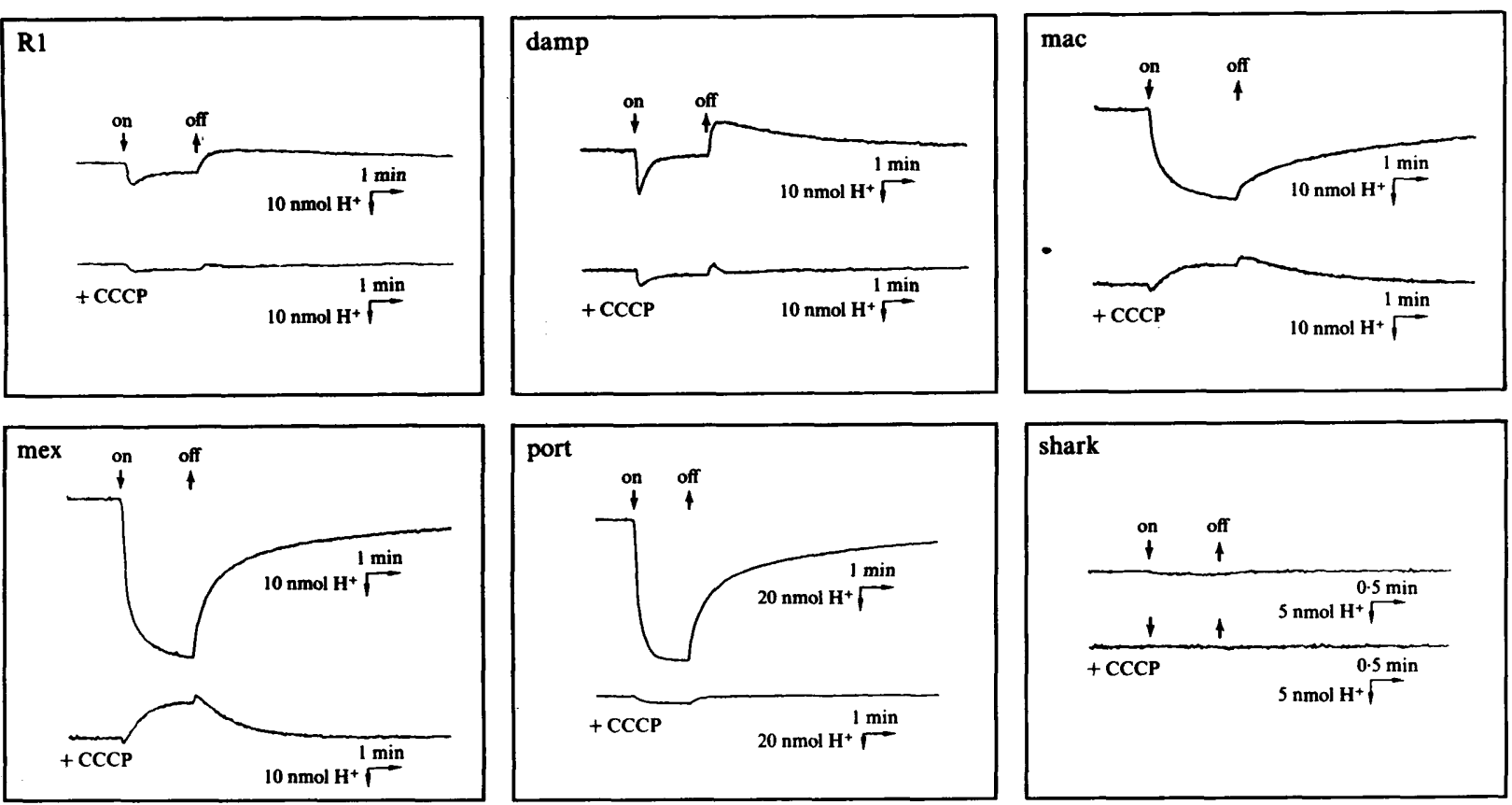

Fig. 3. Light-induced pH change of cell envelope vesicles suspension from various halobacterial strains. Proton transport was followed by $\mathrm{pH}$ change with (lower curve) and without (upper curve) CCCP $(50 \mu \mathrm{M})$. The vesicles were suspended in $3 \mathrm{M}-\mathrm{KCl}$ and $1 \mathrm{mM}-\mathrm{HEPES}$ buffer at $\mathrm{pH}$ 6.5. The sample contained $1 \mathrm{mg}$ protein $\mathrm{ml}^{-1}$ (in the case of shark, the protein concentration was $2 \mathrm{mg} \mathrm{ml}^{-1}$ ). All measurements were done at $25^{\circ} \mathrm{C}$. Start and stop of the light illumination are indicated by arrows.

inside of the cell membrane. However, in view of the lack of alkalization in the presence of CCCP, strain port probably contains only BR-like pigment and not HR-like pigment. Slight acidification was detected in strain shark, indicating the presence of a small amount of BRlike pigment.

To determine whether these strains contain homologues of the bop and hop genes of $H$. halobium R1, total genomic DNA of the five strains was analysed by Southern blot hybridization. Although significant hybridization with the bop gene probe was observed for the DNA from strain damp (Fig. $4 b$; lanes 3 and 9), only faint signals of DNA fragments from other strains were detected (lanes 4-7 and 10-13) in the same blot. This result indicates that the gene encoding the BR-like pigment found in strain damp is homologous to that of $H$. halobium R1 and that the genes in other strains are not homologous. In the case of the hop gene, significant hybridization with DNA fragments of strain damp was also observed, again suggesting the presence of a homologous hop gene of $H$. halobium R1 (Fig. 4d; lanes 3 and 9). Faint hybridization bands were observed with DNA fragments from strains mac, mex and port (Fig. $4 d$; lanes 4-6 and 10-12), implying the presence of sequences with some homology to the hop gene of $H$. halobium R1. After a longer exposure, we could also observe a fainter signal from DNA fragments of strain shark (Fig. 4d; lanes 7 and 13).
After excitation of $H$. halobium R1 with the flash light $(>620 \mathrm{~nm}$ ), the absorption change at $570 \mathrm{~nm}$ does not recover completely for $100 \mathrm{~ms}$, because of the presence of slow-cycling pigment (recovery half-time $\sim 750 \mathrm{~ms}$ ) in the cell envelope vesicles. This pigment is known as sensory rhodopsin, and has been suggested to mediate both the attractant and repellent photoresponse (Spudich \& Bogomolni, 1984; Tomioka et al., 1986b). Fig. 5 shows the flash-induced absorbance changes at $570 \mathrm{~nm}$ in cell envelope vesicles from various strains within the $3 \mathrm{~s}$ to

Table 3. Presence of $B R-, H R-, S R$ - and PR-like pigment in five new halobacterial strains

The presence and relative amounts of the pigments was estimated from flash-induced absorbance change measurements and ion pump activity measurements, and are indicated by the number of plus signs. PR-like pigment of strain port was detected only in membrane from cells after $2 \mathrm{~d}$ of growth. The presence of HR- and PR-like pigments in strain damp was not confirmed.

\begin{tabular}{|c|c|c|c|c|}
\hline Name & $\mathbf{B R}$ & HR & SR & PR \\
\hline damp & +++ & $(+)$ & + & $(+)$ \\
\hline $\operatorname{mac}$ & ++ & $+t$ & + & ND \\
\hline mex & ++ & ++ & + & ND \\
\hline port & $+t$ & ND & ND & + \\
\hline shark & + & ND & + & ++ \\
\hline
\end{tabular}

ND, Not determined. 

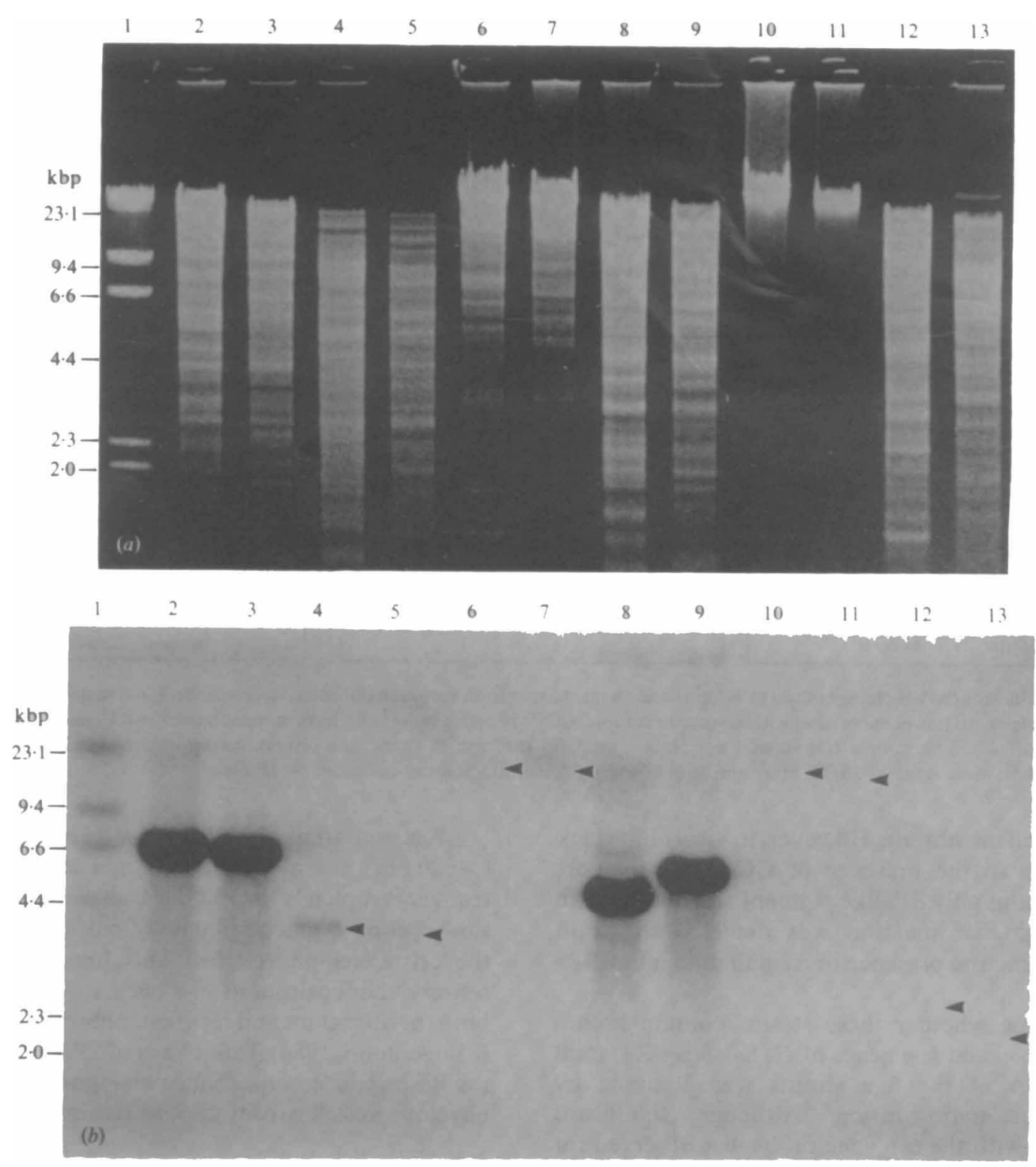

Fig. 4. Southern blot hybridization analysis with the bop and hop genes in the genomic DNA from $H$. halobium strains R1 (lanes 2 and 8), damp (lanes 3 and 9), mac (lanes 4 and 10), mex (lanes 5 and 11), port (lanes 6 and 12) and shark (lanes 7 and 13). Lane 1 is biotinylated lambda DNA digested with HindIII. (a) Restriction patterns of the genomic DNA. Lanes 2 to $7:$ BamHI cleavage; Lanes 8 to 13: Pst I cleavage. (b) Southern blot hybridization with a biotin-labelled probe prepared from the $\sim 800 \mathrm{kbp}$ bop gene fragment. The faint hybridizing bands in lanes 4 to 7 and 10 to 13 are marked by ( $\triangleleft)$. (c) Restriction patterns of the genomic DNA. Lanes 2 to $7:$ SacI cleavage; lanes 8 to 13: SmaI cleavage. (d) Southern blot hybridization with a biotin-labelled probe prepared from the $\sim 600 \mathrm{kbp}$ hop gene fragment. The faint hybridizing bands in lanes 4 to 6 and 10 to 12 are marked by ( $)$. The faint hybridizing band after a longer exposure is marked by $(\bullet)$ in lanes 7 and 13. The bop and hop gene fragments were prepared using PCR technique as described in Methods.

$100 \mathrm{~s}$ time range. A slow-cycling pigment with a recovery half-time of $\sim 750 \mathrm{~ms}$ was observed in strain damp, suggesting the presence of a SR-like pigment similar to that of $\boldsymbol{H}$. halobium R1. In strains mac, mex and shark, similar slow-cycling pigments were observed; however, the recovery half-time was more than 15 times slower than that found in SR of $H$. halobium R1. The flash- induced absorbance difference spectra shown in Fig. 6 are similar to that found in SR from $H$. halobium R1 (Bogomolni \& Spudich, 1982), suggesting the presence of SR-like pigment in strains damp, mac, mex and shark. A slow-cycling SR-like pigment was not observed in strain port.

PR is found in the cell membrane of the BR-, HR- and 

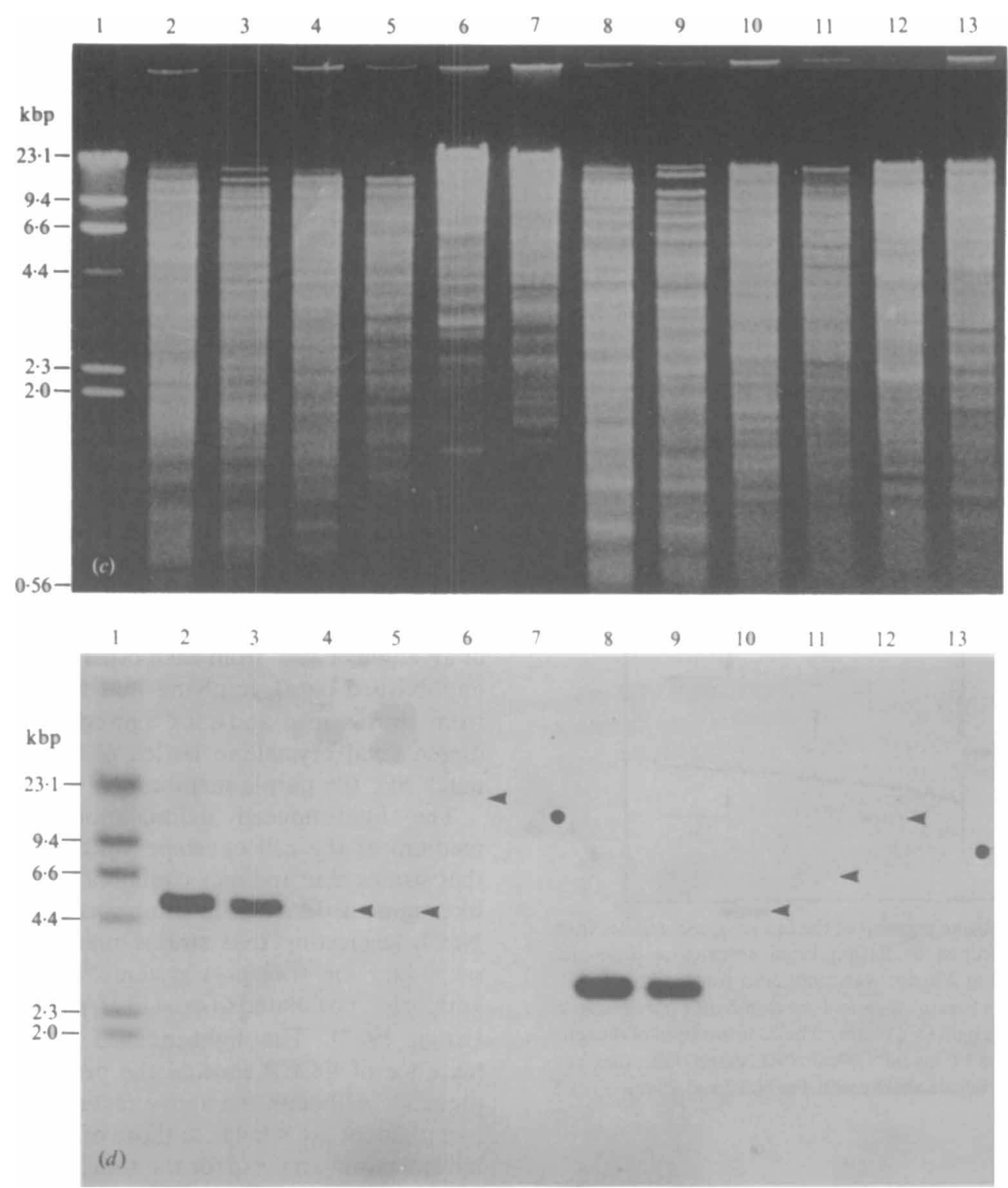

Fig. 4 (cont.).

SR-negative mutant ON1-bW, which is derived from H. halobium R1 (Tomioka et al., 1986a). This pigment functions as the receptor for negative phototaxis (Takahashi et al., 1985). The absorption maximum of PR is $\sim 490 \mathrm{~nm}$ and its photocycle is 2 to 3 times faster than that found in SR. Using an actinic flash of blue light (effective bandpass, $470-500 \mathrm{~nm}$ ), only a PR pigment in the cell envelope vesicles should be excited. The flashinduced absorbance difference spectra and the transient absorbance changes at $450 \mathrm{~nm}$ are shown in Fig. 7. We detected a PR-like pigment only from the cell envelope vesicle of strains port and shark. The flash-induced difference spectrum and the kinetics of the absorbance change at $450 \mathrm{~nm}$ of strains port and shark are almost identical to those of ON1-bW. These results strongly imply the presence of a PR-like pigment in these strains. We could not clearly detect the absorption changes between 350 and $650 \mathrm{~nm}$ in strains damp, mac and mex, because of the contributions from other absorption changes (BR, HR and carotenoid). A mutant strain without $B R, H R$ and carotenoid is necessary to confirm the presence of PR-like pigment in the cell membrane from these strains.

Treatment with hydroxylamine is known to remove retinal from BR, HR, SR and PR (Oesterhelt et al., 1974; Lanyi \& Schobert, 1983; Tomioka et al., 1986a). The cell envelope vesicles of all strains were exposed to $0.4 \mathrm{M}$ hydroxylamine at $\mathbf{p H ~ 7 . 0 ~ i n ~ t h e ~ l i g h t . ~ A f t e r ~ i n c u b a t i o n ~}$ for $24 \mathrm{~h}$, there was a decrease in the flash-induced absorbance changes of BR-, SR- and PR-like pigments. 


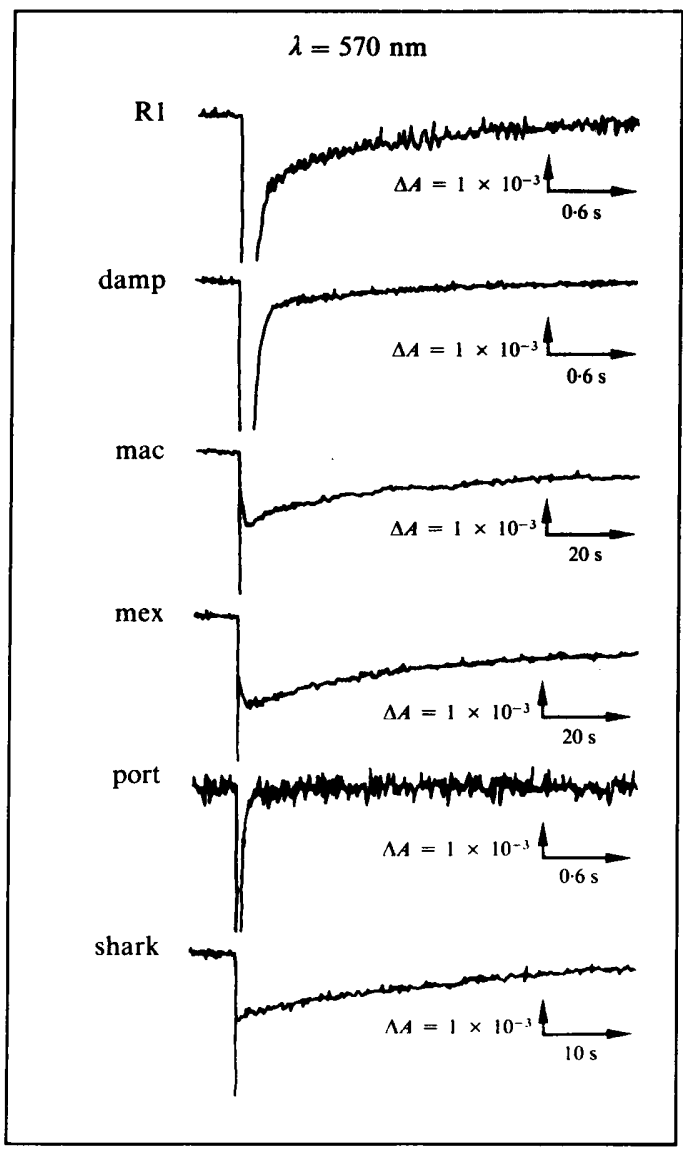

Fig. 5. Presence of SR-like pigment in the cell envelope vesicles from various strains determined by flash-induced absorbance difference changes. The change at $570 \mathrm{~nm}$ was monitored for $3 \mathrm{~s}$ (strains R1, damp and port), $100 \mathrm{~s}$ (strains mac and mex) and $50 \mathrm{~s}$ (strain shark) after a red actinic flash light $(>610 \mathrm{~nm})$. The concentration of the total membrane protein was $1.0 \mathrm{mg} \mathrm{ml}^{-1}$ (strains R1, damp, mac, mex and port) and $2.0 \mathrm{mg} \mathrm{ml}^{-1}$ (strain shark) with $4 \mathrm{M}-\mathrm{NaCl}$ and $25 \mathrm{mM}$-PIPES at $\mathbf{p H} \mathbf{7 . 0}$.

Addition of all-trans-retinal to these membranes after removal of hydroxylamine resulted in the reconstitution of photochemically active pigments, showing that all pigments required retinal (data not shown).

\section{Discussion}

Flash-induced absorbance changes and light-induced ion pump activities revealed that five newly isolated halobacterial strains have some retinal proteins. The presence of retinal pigments in the five strains is summarized in Table 3.

Photocycling rate and flash-induced difference spectra of both BR-like and SR-like pigments in cell envelope vesicles strongly suggest that bacteriorhodopsin and sensory rhodopsin from strain damp are very similar to those in $H$. halobium R1. Hybridization analysis also indicated that the DNA from strain damp contained sequences homologous to both the bop and hop genes of $H$. halobium R1 (Fig. 4). Strain damp DNA was also homologous to the sensory opsin (sop) gene of $H$. halobium R1 (data not shown). Therefore, strain damp could contain the same retinal proteins as $H$. halobium R1.

Although strains mac and mex were independently isolated from Australia and Mexico, flash-induced absorbance changes and light-induced ion pump activities indicate that mac and mex strains contain similar retinal proteins. By washing the envelope vesicles from these two strains in water, we isolated a red-purplecoloured membrane in contrast with purple membrane from $H$. halobium R1. SDS-PAGE of this red-purplecoloured patch showed a single band with a molecular mass of $\sim 26 \mathrm{kDa}$ (data not shown), which is similar to that of BR. This membrane patch was also air-dried and observed by electron microscopy. Some cracks, formed at an angle of $120^{\circ}$ from each other, were observed (our unpublished data), implying that the BR-like pigment from strains mac and mex aggregates to form a twodimensional crystalline lattice of the cell membrane, much like the purple membrane.

The light-induced acidification of the external medium of the cell envelope vesicles clearly indicates that strains mac and mex contain a large amount of BRlike pigment. This acidification was also detected in $4 \mathrm{M}$ $\mathrm{NaCl}$, suggesting that strains mac and mex have no secondary ion transport systems, such as an $\mathrm{Na}^{+} / \mathrm{H}^{+}$ antiporter, postulated to exist in H. halobium (Schobert \& Lanyi, 1982). The light-induced alkalization in the presence of CCCP showed the presence of a HR-like pigment. Although the above features of BR- and HRlike pigment are similar to those of $H$. halobium R1, the hybridization analysis for the total genomic DNA with bop and hop gene probes clearly indicated that the genes encording the BR- and HR-like pigments were not homologous to those of $H$. halobium R1. In addition, the photocycle of the SR-like pigment differed from that of SR from $H$. halobium R1. Therefore, strains mac and mex and their retinal proteins are not identical to H. halobium R1.

Although strain port contained a relatively large amount of BR-like pigment, neither purple membrane nor the red-purple-coloured membrane patch was isolated by washing in water. In contrast with purple membrane, this BR-like pigment probably does not make a specialized patch in the cell membrane. Therefore, this BR-like pigment seems to be different from that of strains mac and mex.

Although the flash-induced absorbance difference spectrum of the SR-like pigment is almost identical to 

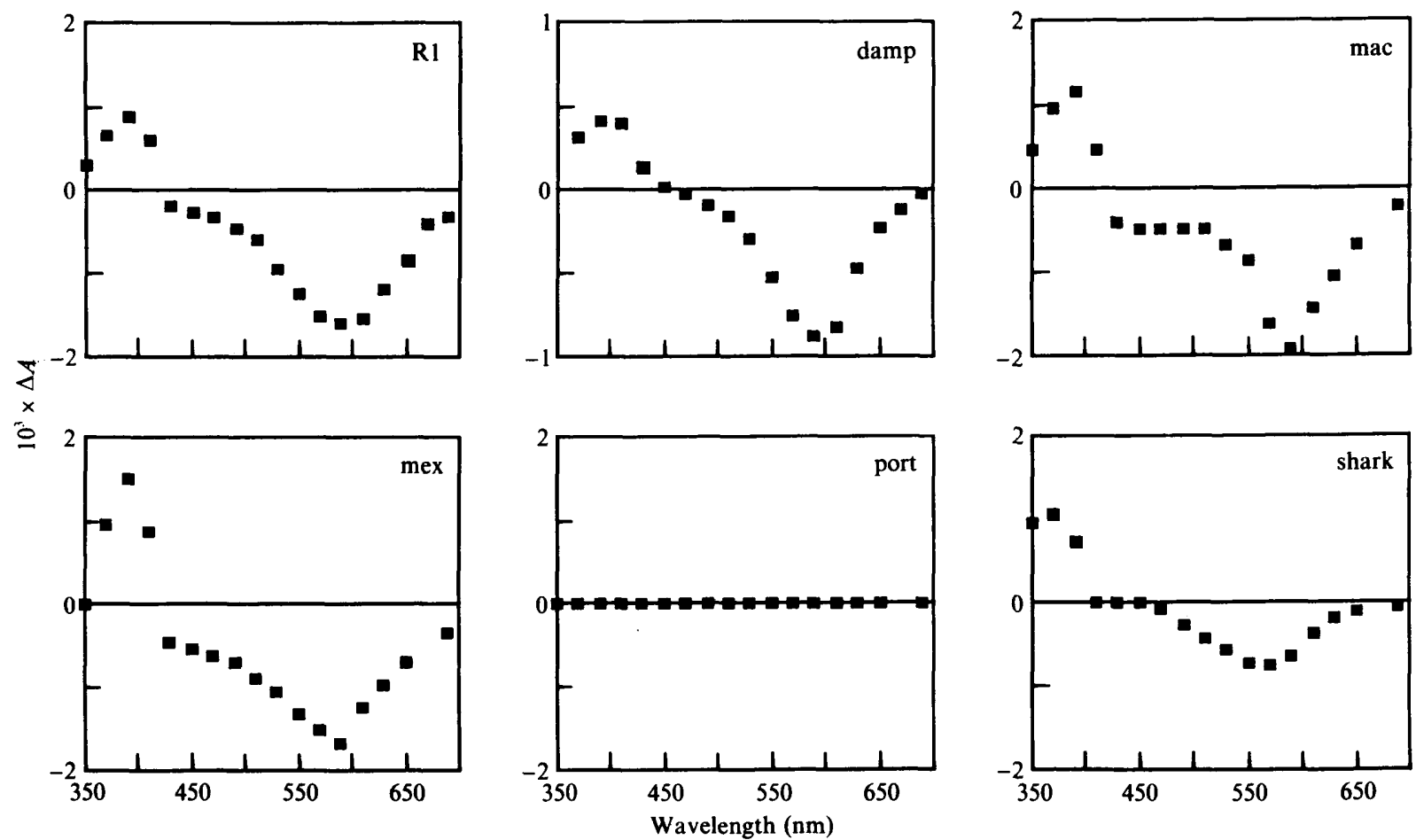

Fig. 6. Flash-induced absorbance difference spectra of the SR-like pigment. Each spectrum was obtained from the absorbance change $300 \mathrm{~ms}$ (strains R1, damp and port) or $10 \mathrm{~s}$ (strains mac, mex and shark) after the flash at various wavelengths (350 to $700 \mathrm{~nm}$ ). Sample concentration was as described in Fig. 5.
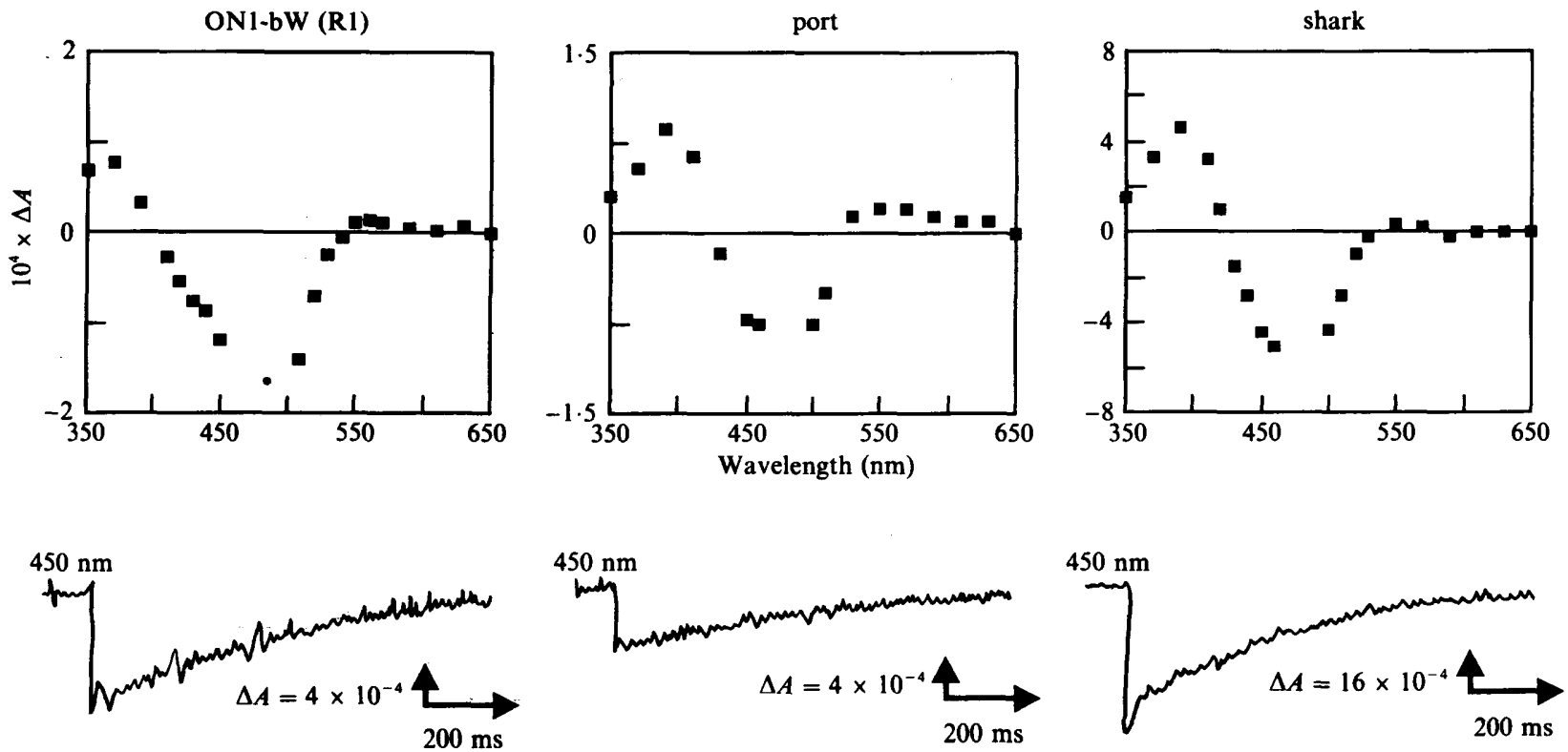

Fig. 7. Presence of PR-like pigment in the cell envelope vesicles from strains ON1-bw, port and shark determined by flash-induced absorbance changes. Flash-induced absorbance difference spectra and the change in absorbance at $450 \mathrm{~nm}$ for $1 \mathrm{~s}$ after an actinic flash light (effective bandpass, 470 to $500 \mathrm{~nm}$ ) are shown. Spectra were obtained from the absorbance change $100 \mathrm{~ms}$ after the flash at various wavelengths ( 350 to $650 \mathrm{~nm}$ ). In strain port, cells in early exponential growth phase ( $2 \mathrm{~d})$ were used. The concentration of the total membrane protein was $2.0 \mathrm{mg} \mathrm{ml}^{-1}$ with $4 \mathrm{M}-\mathrm{NaCl}$ and 25 mM-PIPES at $\mathrm{pH} 7.0$. 
that of $H$. halobium $\mathrm{R} 1$, its photocycle in strains mac, mex and shark is more than 15 times slower than that of $H$. halobium $\mathrm{R} 1$. This photocycle results in an increase in its intermediate form, which presumably mediates the repellent photoresponse by near-UV light. Therefore, these strains may be more sensitive to UV light under physiological conditions. It was suggested that the charge displacement by the amino acid replacement (Asp-96 in BR is replaced by Tyr-87 in SR) of the proton donor to the Schiff base caused the slow-cycling of SR (Blanck et al., 1989). If this assumption is correct, this SR-like pigment would have a more positively charged residue instead of $\mathrm{Tyr}$ in this position.

At present, only one BR-like pigment (archaerhodopsin) in Australian Halobacterium (Halobacterium sp. aus-1) has been isolated, characterized and sequenced (Mukohata et al., 1988; Sugiyama et al., 1989). This pigment exists in the red-purple-coloured membrane patch (called claret membrane) similar to the BR-like pigment in strains mac and mex. A HR-like pigment, however, has not been detected in Halobacterium sp. aus-1. Therefore, this strain could be different from strains mac and mex. A number of $\boldsymbol{H}$. halobium strains containing purple membrane have been isolated (Pfeifer, 1986). Their genetic features have been characterized and some differences between these strains have been revealed. However, the sequence of all these BRs have not yet been determined. Only BR in $H$. halobium strain GRB, which is genetically stable, has been sequenced and found to be identical to that of $H$. halobium (Soppa $e t$ al., 1989). Halobacterial strains containing purple membranes could be widespread under extremely halophilic conditions, and strain damp, isolated from Australia, is one such.

Crude solar salts were kindly provided by Japan Tobacco Inc. We thank Mrs Yasuko Urabe for her assistance with DNA hybridization analysis. We would like to express our gratitude to Dr Naoki Kamo for his helpful discussion. This work was supported in part by a grant for 'Special Researchers' Basic Science Program' given by the Science and Technology Agency of the Japanese Government.

\section{References}

Bivin, D. B. \& Stoeckenius, W. (1986). Photoactive retinal pigments in haloalkaliphilic bacteria. Journal of General Microbiology 132, 2167-2177.

Blanck, A. \& Oesterhelt, D. (1987). The halo-opsin gene. III. Sequence, primary structure of halorhodopsin and comparison with bacteriorhodopsin. EMBO Journal 6, 265-273.

Blanck, A., Oesterhelt, D., Ferrando, E., Schegk, E. S. \& LoTTSPEICH, F. (1989). Primary structure of sensory rhodopsin I, a prokaryotic photoreceptor. EMBO Journal 8, 3963-3971.

BogomolNI, R. A. \& SPUDICH, J. L. (1982). Identification of a third rhodopsin-like pigment in phototactic Halobacterium halobium. Proceedings of the National Academy of Sciences of the United States of America 79, 6250-6254.
Dunn, R., McCoy, J., Simesk, J. M., Majumdar, A., Chang, S. H., RAJBHANDARY, U. L. \& KHORANA, H. G. (1981). The bacterioopsin gene. Proceedings of the National Academy of Sciences of the United States of America 78, 6744-6748.

Duschl, A., Lanyi, J. K. \& Zimanyi, L. (1990). Properties and photochemistry of a halorhodopsin from the Haloalkalophile, Natronobacterium pharaonis. Journal of Biological Chemistry 265, 1261-1267.

Henderson, R., Baldwin, J. M., Cesska, T. A., Zemlin, F., BeCKMANN, E. \& Downing, K. H. (1990). Model for the structure of bacteriorhodopsin based on high-resolution electron cryomicroscopy. Journal of Molecular Biology, 213, 899-929.

Kouyama, T., Kouyama, A. N. \& IKegami, A. (1987). Bacteriorhodopsin is a powerful light-driven proton pump. Biophysical Journal 51, 839-841.

KhORANa, H. G. (1988). Bacteriorhodopsin, a membrane protein that uses light to translocate protons. Journal of Biological Chemistry 263, 7439-7442.

LANYI, J. K. \& SCHOBERT, B. (1983). Effects of chloride and pH on the chromophore and photocycling of halorhodopsin. Biochemistry 22 , 2763-2769.

Lanyi, J. K., Duschi, A., Hatfield, G. W., May, K. \& Oesterhelt, D. (1990). The primary structure of a halorhodopsin from Natronobacterium pharaonis. Journal of Biological Chemistry 265, 12531260.

LI, Q, Govindjee, R. \& EbReY, T. G. (1986). A proton release site on the C-terminal side of bacteriorhodopsin. Photochemistry and Photobiology 44, 515-518.

Matsuno-Yagi, A. \& Muxohata, Y. (1977). Two possible roles of bacteriorhodopsin; a comparative study of strains of Halobacterium halobium differing in pigmentation. Biochemical and Biophysical Research Communications 78, 237-243.

Mogi, T., Stern, L. J., Marti, T., Chao, B. H. \& Khorana, H. G. (1988). Aspartic acid substitutions affect proton translocation by bacteriorhodopsin. Proceedings of the National Academy of Sciences of the United States of America 85, 4148-4152.

Mukohata, Y., SugiYama, Y., Ihara, K. \& Yoshida, M. (1988). An Australian halobacterium contains a novel proton pump retinal protein: archaerhodopsin. Biochemical and Biophysical Research Communications 151, 1339-1345.

Oesterhelt, D. \& StozCKenIus, W. (1971). Rhodopsin-like protein from the purple membrane of Halobacterium halobium. Nature New Biology 233, 149-152.

Oesterhelt, D. \& Stoeckenius, W. (1974). Isolation of the cell membrane of Halobacterium halobium and its fractionation into red and purple membrane. Methods in Enzymology 31, 667-678.

Oesterhelt, D., SchummanN, L. \& Gruber, H. (1974). Lightdependent reaction of bacteriorhodopsin with hydroxylamine in cell suspensions of Halobacterium halobium: demonstration of an apomembrane. FEBS Letters 44, 257-261.

Otto, H., Marti, T., Holz, M., Mogi, T., Stern, L. J., Engel, F., Khorana, H. G. \& HeYN, M. P. (1990). Substitution of amino acids Asp-85, Asp-96, and Arg-82 in bacteriorhodopsin affects the proton release phase of the pump and pK of the Schiff base. Proceedings of the National Academy of Sciences of the United States of America 87, 1018-1022.

PFEIFER, F. (1986). Insertion elements and genome organization of Halobacterium halobium. Systematic and Applied Microbiology 7, 36-40.

SCHOBERT, B. \& LANYI, J. K. (1982). Halorhodopsin is a lightdriven chloride pump. Journal of Biological Chemistry 257, 1030610313.

Soppa, J., Otomo, J., Straub, J., Tittor, J., Meessen, S. \& OESTERHELT, D. (1989). Bacteriorhodopsin mutants of Halobacterium sp. GRB. II. Characterization of mutants. Journal of Biological Chemistry 264, 13049-13056.

SPUdich, J. L. \& BogomolNI, R. A. (1984). The mechanism of colour discrimination by a bacterial sensory rhodopsin. Nature, London 312 , 509-513.

Stozckenius, W., Lozier, R. H. \& Bogomolni, R. A. (1979). Bacteriorhodopsin and the purple membrane of Halobacteria. Biochimica et Biophysica Acta 505, 215-278. 
Sugiyama, Y., Maeda, M., Futai, M. \& Mukohata, Y. (1989). Isolation of a gene that encodes a new retinal protein, achaerhodopsin, from Halobacterium sp. aus-1. Journal of Biological Chemistry 264, 20859-20862.

Takahashi, T., Tomioka, H., Kamo, N. \& Kobatake, Y. (1985). A photosystem other than PS370 also mediates the negative phototaxis of Halobacterium halobium. FEMS Microbiology Letters 28, 161-164.

Tomioka, H., Takahashi, T., Kamo, N. \& Kobatake, Y. (1986a). Flash-spectrophotometric identification of a fourth rhodopsin-like pigment in Halobacterium halobium. Biochemical and Biophysical Research Communications 139, 389-395.
Tomioka, H., Takahashi, T., Kamo, N. \& Kobatake, Y. (1986b). Action spectrum of the photoattractant response of Halobacterium halobium in early logarithmic growth phase and role of sensory rhodopsin. Biochimica et Biophysica Acta 884, 578-584.

Vogelsang, H., Oertel, W. \& Oesterhelt, D. (1983). The isolation of the bacterioopsin gene. Methods in Enzymology 97, 226-241.

Woese, C. R., Kandler, O. \& Wheelis, M. A. (1990). Towards a natural system of organisms: Proposal for the domains Archaea, Bacteria, and Eucarya. Proceedings of the National Academy of Sciences of the United States of America 87, 4576-4579. 